\title{
On the Relevance of Exchange Rate Regimes for
}

\section{Stabilization Policy*}

\author{
Bernardino Adaoł Isabel Correia; and Pedro Teles ${ }^{\S}$
}

November, 2006

\begin{abstract}
This paper assesses the relevance of the exchange rate regime for stabilization policy. Using both fiscal and monetary policy, we conclude that the exchange rate regime is irrelevant. This is the case independently of the severity of price rigidities, independently of asymmetries across countries in shocks and transmission mechanisms and regardless of the incompleteness of international financial markets. The only relevant condition is on labor mobility. The results can be summarized with the claim that every currency area is an optimal currency area, provided labor is not mobile across countries.
\end{abstract}

JEL classification: E31; E63; F20; F33; F41; F42

Key words: Optimal currency areas; Monetary union; Fixed exchange rates; Fiscal and monetary policy; Stabilization Policy; Labor mobility; Nominal rigidities

${ }^{*}$ We thank participants at the 2005 SED Meetings in Budapest, the Banco de Portugal/CEPR Conference on Exchange Rates and Currencies, and at seminars at UCL and Banca d'Italia. We gratefully acknowledge financial support of FCT.

${ }^{\dagger}$ Banco de Portugal

¥Banco de Portugal, Universidade Catolica Portuguesa and CEPR.

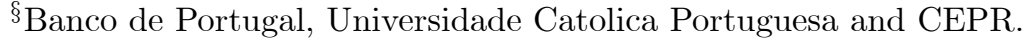




\section{Introduction}

This paper revisits the issues in the optimal currency area literature initiated by Mundell (1961). What are the costs of a fixed exchange rate regime, or a monetary union, when there is a role for stabilization policy? We address this question allowing for heterogeneity in the shocks and the response to them, restrictions on the mobility of factors and incompleteness of asset markets, as is standard in the optimal currency area literature.

When different shocks hit different countries or when there are differences across countries in the effects of shocks, monetary policy, that has a stabilization role because of some form of nominal rigidity, may have to react differently in the different countries. Because of this heterogeneity it is common to infer that there are costs of coordinating monetary policies, either through a fixed exchange rate regime or a monetary union. In the literature, these costs are taken to be higher the stronger are the asymmetries, the more severe are the nominal rigidities, the more pronounced is the incompleteness of international asset markets, the less mobile is labor, and, finally, the less able is fiscal policy in effectively stabilizing the national economies $\left(\right.$ Corsetti, 2005) ${ }^{1}$.

We take the standard approach in the literature on optimal fiscal and monetary policy after Lucas and Stokey (1983), followed by many others. There, fiscal and monetary policy are decided jointly by a Ramsey government that must raise distortionary taxes to pay for exogenous government expenditures, so that the Pareto first best solution is not achievable. We show that the loss of the country specific monetary tool is of no cost. This is true irrespective of the asymmetry in shocks or response to these and the severity of the nominal rigidities. The elements that turn

\footnotetext{
${ }^{1}$ See also Corsetti (2006).
} 
out to be crucial in assessing the costs of a single monetary policy are the two last ones in the list by Corsetti above, but labor mobility works in the opposite way to the conventional wisdom. Fiscal and monetary policy are able to eliminate the costs of a monetary union only if labor is not mobile across countries.

We consider a standard two country model. Each country specializes in the production of a composite tradeable good, which aggregates a continuum of goods produced using labor only. Labor is not mobile across countries. Money is used for transactions according to a cash-in-advance constraint on the purchases of the two composite goods by the households of each country. The government of each country must finance exogenous expenditures on the good produced at home with distortionary taxes and seigniorage. The tax instruments are labor income and consumption taxes. There is state-contingent private debt inside each country in zero net supply and noncontingent nominal public debt in each currency that can be traded internationally.

We start by analyzing a benchmark economy where prices are flexible (sections 2 and 3). We show that any equilibrium allocation in the flexible price, flexible exchange rates, economy can be implemented with fiscal and monetary policies that induce stable producer prices and constant exchange rates. This result has implications for economies under fixed exchange rates with nominal rigidities (Section 4). For those policies, that under flexible prices keep prices constant, if firms were restricted in the setting of prices such as in Calvo (1983), those restrictions would be irrelevant and the same allocations could still be implemented. It follows that under sticky prices and fixed exchange rates it is always possible to achieve the same allocations as under flexible prices and exchange rates.

Under sticky prices there are equilibrium allocations other than the ones achieved under flexible prices. We show that the common set of allocations to flexible and 
sticky prices dominates in welfare terms those other equilibrium allocations.

When prices are sticky, one would think that flexible exchange rates would be useful in adjusting the relative price of goods to different shocks. In our model, because we allow for consumption taxes the relative price is the ratio of prices gross of consumption taxes, adjusted by the nominal exchange rate. When the exchange rate is fixed, consumption taxes have a direct effect on the relative price and change in response to shocks so that the necessary adjustments take place. Labor income taxes will also have to be adjusted so that other margins may not be affected.

Exchange rate policy can play other roles such as completing the noncontingent international financial markets. Again, when the exchange rates are fixed, taxes, and interest rates common across countries, play that same role of allowing for the returns on assets traded internationally to vary with the shocks².

Labor immobility is a crucial assumption for our results. The irrelevance results do not hold in an alternative model with labor mobility (Section5). This goes against the standard intuition in the optimal currency area literature. Labor mobility imposes additional equilibrium restrictions, in particular arbitrage conditions on the choice of where to work, that cannot be satisfied with the policy instruments that we consider. This of course does not imply that welfare with labor mobility is lower than without it.

Related literature reassesses Milton Friedman (1953)'s case for exchange rate flexibility, as a way of side-stepping the rigidity in relative price movements. Recent examples in the debate are, for instance, Devereux and Engle (2003) and Duarte and Obstfeld (2005). ${ }^{3}$ Devereux and Engle (2003) provide an example with local currency

\footnotetext{
${ }^{2}$ See Chari, Christiano and Kehoe (1991), Schmitt-Grohe and Uribe (2004), Siu (2004) Correia, Nicolini and Teles (2002), Aiyagari, Marcet, Sargent and Seppala (2002) for optimal policy without state contingent public debt in a closed economy. See also Angeletos (2002), and Buera and Nicolini (2004), on the use of debt of different maturities as a way of completing asset markets.

${ }^{3}$ See also Obstfeld (2004) and Duarte (2004).
} 
pricing where exchange rate flexibility is of no use. Because the prices of goods are set in the currency of the consumers, the exchange rate cannot affect the relative price. Duarte and Obstfeld (2004) respond, showing that exchange rate flexibility can still be of use in a more complex environment with non tradeable goods. Even if exchange rate movements cannot affect the relative price of goods, they can still affect the allocations and improve welfare. Because the optimal exchange rate regime depends on the degree of exchange rate pass-through, Corsetti and Pesenti (2002) allow for the decision on which currency prices are set in to be endogenous. They show that there are two self validating regimes, one with fixed and another with flexible exchange rates. The flexible exchange rate regime provides higher welfare. Our paper questions the generality of the exercises in these papers. We show that the claims hinge on the focus on monetary policy only. ${ }^{4}$ Once the choice of the exchange rate regime is considered in the context of the full choice of policy instruments including tax and debt policy, exchange rate flexibility can be replaced with a gain by fiscal instruments. In the set up of Devereux and Engle (2003), the exchange rate regime would still be irrelevant, but it would be possible to implement better allocations; the remark of Duarte and Obstfeld would not go through; and the two regimes in Corsetti and Pesenti (2002), flexible or fixed exchange rates, would provide the same welfare.

Cooper and Kempf (2004) make a similar point to ours in a very different context. They explicitly model the Mundellian trade-off between the benefits of a monetary union in reducing transaction costs and the costs of the union in the ability to stabilize. Stabilization in their set up are risk sharing transfers between agents. If the government is able to stabilize using alternative fiscal instruments, then there are no costs of a monetary union.

\footnotetext{
${ }^{4}$ On recent work on optimal monetary policy in a currency area see Benigno (2004).
} 
Gali and Monacelli (2005) and Ferrero $(2005)^{5}$ consider both fiscal and monetary policy in a set up closer to ours, but restrict the set of fiscal policy instruments. For that reason, they are unable to establish the irrelevance results that we obtain. In Gali and Monacelli (2005) the government chooses the optimal level of public consumption in a monetary union with lump-sum taxes. The use of state contingent public consumption is useful, but is not a substitute for exchange rate flexibility. Ferrero (2005), like us, considers that lump-sum taxes are not available. He solves a very similar policy problem to the one we solve with the main difference that consumption taxes are not considered. He allows for state contingent labor income taxes, but not for consumption taxes. It turns out that that assumption is crucial. While we are able to establish that exchange rate flexibility is irrelevant, in Ferrero all fiscal policy does is help attain higher welfare. There is still a cost of a monetary union.

We assume that both fiscal and monetary policy variables are state contingent. Because our question is a regime question, we think that the natural assumption is to allow for alternative fiscal and monetary institutions, other than the ones we observe. This was the approach in Lucas and Stokey (1983), followed by the subsequent literature (see Chari, Christiano and Kehoe's multiple contributions, ${ }^{6}$ Correia, Nicolini and Teles (2002), Schmitt-Grohe and Uribe (2004), Siu (2004), Benigno and Woodford (2003), and, in the open economy, Benigno and Paoli (2004), Ferrero (2005) among others). We don't think there are fundamental reasons for taxes not to be state contingent. If there were, then they should probably also apply to monetary policy, given that monetary policy in the models that we use acts essentially like fiscal policy. But

\footnotetext{
${ }^{5}$ There is related work on optimal fiscal and monetary policy in small open economies. In Nicolini and Hevia (2004), even if prices are sticky, the second best, flexible price equilibrium is implementable, but exchange rates must move across states. See also Benigno and Paoli (2004).

${ }^{6}$ See, in particular, Chari, Christiano and Kehoe (1991) and Chari and Kehoe (1999).
} 
since we do observe that monetary policy is very flexible, most likely, there is nothing preventing fiscal policy from being as flexible.

\section{The Model}

The economy has two countries of equal size, the home country and the foreign country. In each country there is a representative household, a continuum of firms and a government. Each firm produces a distinct, perishable consumption good with labor only. In each period $t=0,1, \ldots, T$, where $T$ can be made arbitrarily large, ${ }^{7}$ the economy experiences one of finitely many events $s_{t}$. The initial realization $s_{0}$ is given. The set of all possible events in period $t$ is denoted by $S_{t}$, the history of these events up to and including period $t$, which we call state at $t,\left(s_{0}, s_{1}, \ldots, s_{t}\right)$, is denoted by $s^{t}$, and the set of all possible states in period $t$ is denoted by $S^{t}$. The number of all possible states in period $t$ is $\# S^{t}$. All the relevant variables for this world economy are a function of the state, $s^{t}$, but to simplify the notation we do not index formally the variables to the state.

There are markets for goods, labor, money, state-contingent debt and statenoncontingent debt. The labor market is segmented across countries. The statecontingent debt market is segmented across countries and across households and governments. The goods and the state-noncontingent debt are tradeable across countries and agents. In this section we assume that firms set prices every period with contemporaneous information. We also assume that exchange rates are flexible.

\footnotetext{
${ }^{7}$ The assumption of a finite, even if arbitrarily large, time horizon considerable simplifies the analysis and is as reasonable an assumption as the more standard one of an infinite horizon.
} 


\subsection{The households}

The preferences of the home households are described by the expected utility function:

$$
U=E_{t} \sum_{t=0}^{T} \beta^{t} u\left(C_{h, t}, C_{f, t}, L_{t}\right)
$$

$C_{h, t}$ is the home composite consumption good that aggregates the goods produced by the home firms. There is a continuum of home firms in the unit interval $[0,1]$, indexed by $i$.

$$
C_{h, t}=\left[\int_{0}^{1} C_{h, t}(i)^{\frac{\theta-1}{\theta}} d i\right]^{\frac{\theta}{\theta-1}}, \theta>1
$$

where $C_{h, t}(i)$ is the consumption of the good produced by firm $i . C_{f, t}$ is the foreign composite consumption good aggregating the goods produced by the foreign firms,

$$
C_{f, t}=\left[\int_{0}^{1} C_{f, t}(j)^{\frac{\theta-1}{\theta}} d j\right]^{\frac{\theta}{\theta-1}}, \theta>1 .
$$

There is also a continuum of these firms in the unit interval, indexed by $j . L_{t}$ is leisure time and is equal to $1-N_{t}$, where $N_{t}$ is total time devoted to production.

The preferences of the foreign households are described by an identical expected utility function:

$$
U=E_{t} \sum_{t=0}^{T} \beta^{t} u\left(C_{h, t}^{*}, C_{f, t}^{*}, L_{t}^{*}\right),
$$

where $C_{h, t}^{*}$ is the foreign households composite consumption of the goods produced in the home country and $C_{f, t}^{*}$ is the foreign households composite consumption of the goods produced in the foreign country.

The households of either country minimize expenditure in the home and foreign 
goods to obtain a given aggregate consumption of either good. This implies

$$
C_{h, t}(i)=\left(\frac{P_{h, t}(i)}{P_{h, t}}\right)^{-\theta} C_{h, t} \text { and } C_{f, t}(j)=\left(\frac{P_{f, t}^{*}(j)}{P_{f, t}^{*}}\right)^{-\theta} C_{f, t}
$$

where

$$
P_{h, t}=\left[\int_{0}^{1} P_{h, t}(i)^{1-\theta} d i\right]^{\frac{1}{1-\theta}} \text { and } P_{f, t}^{*}=\left[\int_{0}^{1} P_{f, t}^{*}(j)^{1-\theta} d j\right]^{\frac{1}{1-\theta}}
$$

where $P_{h, t}(i)$ is the price of the good produced by the home firm $i$ in units of domestic currency, and $P_{f, t}^{*}(j)$ is the price of the good produced by the foreign firm $j$ in units of foreign currency. Expenditure in either composite good purchased by the home households can then be written as

$$
\int_{0}^{1} P_{h, t}(i) C_{h, t}(i) d i=P_{h, t} C_{h, t} \text { and } \int_{0}^{1} P_{f, t}^{*}(i) C_{f, t}(i) d i=P_{f, t}^{*} C_{f, t} .
$$

Similar expressions are obtained for the households of the foreign country.

The budget constraints can then be written in terms of the aggregate variables. The representative household of the home country at the beginning of each period $t=0,1, \ldots, T+1,{ }^{8}$ uses the nominal wealth $\mathbb{W}_{t}$ to buy $M_{t}$ (home money), $B_{h, t}$ (home government noncontingent debt), $B_{f, t}$ (foreign government noncontingent debt) and $B_{t+1}$ (home private state-contingent debt). The home government noncontingent debt pays the gross return $R_{t}$ in the domestic currency at the beginning of the following period, and the foreign government noncontingent debt pays gross return $R_{t}^{*}$ in foreign currency. The price, normalized by the probability of occurrence of the state, at date

\footnotetext{
${ }^{8}$ Notice that the decision on assets is made also in period $T+1$, while the last period in which agents agents produce and consume is $T$. The assumption that there is an additional subperiod with an assets market for the clearing of debts guarantees that money has value in a finite horizon economy. Agents will want to take money to period $T+1$ to settle debts, that in the aggregate must be with the government. If the finite horizon economy ended with a goods market at $T$, then sellers would not accept money in period $T$, and therefore money would not have value, not only in that period but in every period.
} 
$t$ of one unit of domestic currency at a particular state at date $t+1$ is $Q_{t, t+1}$. There is no government state-contingent debt and the home household cannot buy foreign contingent debt. The price of one unit of foreign currency in units of home currency is $\varepsilon_{t}$. Thus, the following restrictions must be satisfied, respectively, for the home and the foreign households,

$$
\begin{aligned}
& M_{t}+B_{h, t}+\varepsilon_{t} B_{f, t}+E_{t} B_{t+1} Q_{t, t+1} \leq \mathbb{W}_{t} . \\
& M_{t}^{*}+\frac{B_{h, t}^{*}}{\varepsilon_{t}}+B_{f, t}^{*}+E_{t} B_{t+1}^{*} Q_{t, t+1}^{*} \leq \mathbb{W}_{t}^{*} .
\end{aligned}
$$

In the home country there are taxes on the consumption of home produced goods, $\tau_{h, t}$, on the consumption of foreign produced goods, $\tau_{f, t}$, labor income $\tau_{n, t}$ and profits. As the tax on profits is a lump-sum tax it is optimal that all profits be taxed away, so that the net profits are zero. There are corresponding taxes in the foreign country, $\tau_{h, t}^{*}, \tau_{f, t}^{*}, \tau_{n, t}^{*}$.

The wealth home households bring to date $t+1$ is

$$
\begin{aligned}
\mathbb{W}_{t+1}= & M_{t}+B_{h, t} R_{t}+\varepsilon_{t+1} B_{f, t} R_{t}^{*}+B_{t+1}+ \\
& \left(1-\tau_{n, t}\right) W_{t} N_{t}-\left(1+\tau_{h, t}\right) P_{h, t} C_{h, t}-\left(1+\tau_{f, t}\right) \varepsilon_{t} P_{f, t}^{*} C_{f, t} .
\end{aligned}
$$

Money is used to purchase goods according to the following cash-in-advance constraints, for the home and foreign country, respectively,

$$
\begin{aligned}
& \left(1+\tau_{h, t}\right) P_{h, t} C_{h, t}+\left(1+\tau_{f, t}\right) \varepsilon_{t} P_{f, t}^{*} C_{f, t} \leq M_{t}, \\
& \left(1+\tau_{h, t}^{*}\right) \frac{P_{h, t}}{\varepsilon_{t}} C_{h, t}^{*}+\left(1+\tau_{f, t}^{*}\right) P_{f, t}^{*} C_{f, t}^{*} \leq M_{t}^{*} .
\end{aligned}
$$

The households of the home country take prices, policies and initial wealth as 
given and choose allocations and asset positions that maximize expected utility (1) subject to the cash-in-advance constraints (6) and the budget constraints (4) and (5), together with $\mathbb{W}_{T+1} \geq 0$. The households of the foreign country solve a similar problem.

Among the first order conditions for the home and foreign households are the intertemporal conditions for the contingent assets,

$$
\begin{aligned}
& Q_{t-1, t} \frac{u_{C_{h}}(t-1)}{P_{h, t-1}\left(1+\tau_{h, t-1}\right)}=\frac{\beta u_{C_{h}}(t)}{P_{h, t}\left(1+\tau_{h, t}\right)}, \text { all } s^{t-1} \text { and } s^{t} \mid s^{t-1}, 1 \leq t \leq T, \\
& Q_{t-1, t}^{*} \frac{\varepsilon_{t-1} u_{C_{h}^{*}}(t-1)}{P_{h, t-1}\left(1+\tau_{h, t-1}^{*}\right)}=\frac{\beta \varepsilon_{t} u_{C_{h}^{*}}(t)}{P_{h, t}\left(1+\tau_{h, t}^{*}\right)}, \text { all } s^{t-1} \text { and } s^{t} \mid s^{t-1}, 1 \leq t \leq T,
\end{aligned}
$$

the intertemporal conditions for the noncontingent assets,

$$
\begin{aligned}
\frac{u_{C_{h}}(t-1)}{P_{h, t-1}\left(1+\tau_{h, t-1}\right)}=\beta R_{t-1} E_{t-1}\left[\frac{u_{C_{h}}(t)}{P_{h, t}\left(1+\tau_{h, t}\right)}\right], \text { all } s^{t-1}, 1 \leq t \leq T, \\
\frac{\varepsilon_{t-1} u_{C_{h}}(t-1)}{P_{h, t-1}\left(1+\tau_{h, t-1}\right)}=\beta R_{t-1}^{*} E_{t-1}\left[\frac{\varepsilon_{t} u_{C_{h}}(t)}{P_{h, t}\left(1+\tau_{h, t}\right)}\right], \text { all } s^{t-1}, 1 \leq t \leq T, \\
\frac{u_{C_{h}^{*}}(t-1)}{P_{h, t-1}\left(1+\tau_{h, t-1}^{*}\right)}=\beta R_{t-1} E_{t-1}\left[\frac{u_{C_{h}^{*}}(t)}{P_{h, t}\left(1+\tau_{h, t}^{*}\right)}\right], \text { all } s^{t-1}, 1 \leq t \leq T, \\
\frac{\varepsilon_{t-1} u_{C_{h}^{*}}(t-1)}{P_{h, t-1}\left(1+\tau_{h, t-1}^{*}\right)}=\beta R_{t-1}^{*} E_{t-1}\left[\frac{\varepsilon_{t} u_{C_{h}^{*}}(t)}{P_{h, t}\left(1+\tau_{h, t}^{*}\right)}\right], \text { all } s^{t-1}, 1 \leq t \leq T,
\end{aligned}
$$

and the intratemporal conditions,

$$
\begin{aligned}
& \frac{u_{L}(t)}{u_{C_{h}}(t)}=\frac{W_{t}\left(1-\tau_{n, t}\right)}{P_{h, t} R_{t}\left(1+\tau_{h, t}\right)}, \text { all } s^{t}, 0 \leq t \leq T \\
& \frac{u_{C_{h}}(t)}{u_{C_{f}}(t)}=\frac{\left(1+\tau_{h, t}\right) P_{h, t}}{\left(1+\tau_{f, t}\right) \varepsilon_{t} P_{f, t}^{*}}, \text { all } s^{t}, 0 \leq t \leq T
\end{aligned}
$$




$$
\begin{aligned}
& \frac{u_{L_{t}^{*}}(t)}{u_{C_{f}^{*}}(t)}=\frac{W_{t}^{*}\left(1-\tau_{n, t}^{*}\right)}{P_{f, t}^{*} R_{t}^{*}\left(1+\tau_{f, t}^{*}\right)} \text {, all } s^{t}, 0 \leq t \leq T \\
& \frac{u_{C_{h}^{*}}(t)}{u_{C_{f}^{*}}(t)}=\frac{\left(1+\tau_{h, t}^{*}\right) P_{h, t}}{\left(1+\tau_{f, t}^{*}\right) \varepsilon_{t} P_{f, t}^{*}}, \text { all } s^{t}, 0 \leq t \leq T
\end{aligned}
$$

The budget constraints of the households of each country, (4) and (5), together with the terminal conditions $\mathbb{W}_{T+1} \geq 0$ and $\mathbb{W}_{T+1}^{*} \geq 0$, can be written as intertemporal budget constraints, that at the optimum will hold with equality. For the home country those constraints are the following

$$
\begin{aligned}
& \sum_{s=t}^{T} E_{t} Q_{t, s+1}\left[\left(1+\tau_{h, s}\right) P_{h, s} C_{h, s}+\left(1+\tau_{f, s}\right) \varepsilon_{s} P_{f, s}^{*} C_{f, s}-\left(1-\tau_{n, s}\right) W_{s} N_{s}\right] \\
& +\sum_{s=t}^{T} E_{t} Q_{t, s+1}\left[M_{s}\left(\frac{Q_{t, s}}{Q_{t, s+1}}-1\right)\right]=\mathbb{W}_{t}, \text { all } s^{t}, 0 \leq t \leq T,
\end{aligned}
$$

where $Q_{t, s}=Q_{t, t+1} \ldots Q_{s-1, s}, t \geq 0, s \geq t+1$, and $Q_{t, t}=1$.

Using the marginal conditions, as well as the cash in advance constraints, in the intertemporal budget constraints, we can rewrite the budget constraints for the home country as

$$
\sum_{s=t}^{T} \beta^{s-t} E_{t}\left[\left(u_{C_{h}}(s) C_{h, s}+u_{C_{f}}(s) C_{f, s}-u_{L}(s) N_{s}\right)\right]=\mathbb{W}_{t} \frac{u_{C_{h}}(t)}{P_{h, t}\left(1+\tau_{h, t}\right)}, \text { all } s^{t}, 0 \leq t \leq T,
$$

and for the foreign country as

$$
\sum_{s=t}^{T} \beta^{s-t} E_{t}\left[\left(u_{C_{h}^{*}}(s) C_{h, s}^{*}+u_{C_{f}^{*}}(s) C_{f, s}^{*}-u_{L^{*}}(s) N_{s}^{*}\right)\right]=\mathbb{W}_{t}^{*} \frac{u_{C_{f}^{*}}(t)}{P_{f, t}^{*}\left(1+\tau_{f, t}^{*}\right)} \text {, all } s^{t}, 0 \leq t \leq T \text {. }
$$




\subsection{The government}

The government of each country includes both the fiscal authority and the monetary authority. We assume as is standard in this literature that aggregate public expenditures are exogenous. Each government only consumes goods produced by local firms, and chooses consumption of each good to minimize expenditure on the aggregate level of expenditures, $G_{t}$ for the home country and $G_{t}^{*}$, for the foreign country

$$
G_{t}=\left[\int_{0}^{1} G_{h, t}(i)^{\frac{\theta-1}{\theta}} d i\right]^{\frac{\theta}{\theta-1}}, \theta>1,
$$

and

$$
G_{t}^{*}=\left[\int_{0}^{1} G_{f, t}^{*}(j)^{\frac{\theta-1}{\theta}} d j\right]^{\frac{\theta}{\theta-1}}, \theta>1,
$$

where $G_{h, t}(i)$ is the home government consumption of the good produced by firm $i$ and $G_{f, t}^{*}(j)$ is the foreign government consumption of the good produced in that country by firm $j$.

The home government issues state-noncontingent debt, $B_{h, t}+B_{h, t}^{*}$, and money, $M_{t}^{s}$, and taxes labor income and private consumption, as well as profits. The nominal financial liabilities of the home government at the start of period $t$ are $\mathbb{W}_{t}^{g}$, which can be financed by issuing money and public debt

$$
M_{t}^{s}+B_{h, t}+B_{h, t}^{*}=\mathbb{W}_{t}^{g} .
$$

The nominal financial liabilities the home government brings to the next period are

$$
\begin{aligned}
\mathbb{W}_{t+1}^{g}= & M_{t}^{s}+R_{t} B_{h, t}+R_{t} B_{h, t}^{*}+P_{h, t} G_{t}-\tau_{h, t} P_{h, t} C_{h, t}- \\
& \tau_{f, t} \varepsilon_{t} P_{f, t}^{*} C_{f, t}-\tau_{n, t} W_{t} N_{t}-\Pi_{h, t}
\end{aligned}
$$


where $\Pi_{h, t}$ are the profits of the home firms that are fully taxed. We impose the terminal condition that government liabilities in the terminal period are zero, $\mathbb{W}_{T+1}^{g}=$ 0 . The home government period $t$ intertemporal budget constraint can then be written as

$$
\begin{aligned}
\sum_{s=t}^{T} E_{t} Q_{t, s+1}\left[\tau_{h, s} P_{h, s} C_{h, s}+\tau_{f, s} \varepsilon_{s} P_{f, s}^{*} C_{f, s}+\tau_{n, s} W_{s} N_{s}+\Pi_{h, s}-P_{h, s} G_{s}\right] \\
+\sum_{s=t}^{T} E_{t} Q_{t, s+1} M_{s}^{s}\left(\frac{Q_{t, s}}{Q_{t, s+1}}-1\right)=\mathbb{W}_{t}^{g}, \text { all } s^{t}, 0 \leq t \leq T .
\end{aligned}
$$

There is a similar condition for the government of the foreign country.

\subsection{Firms}

In each country there is a continuum of firms in the unit interval. Each firm produces a distinct, perishable consumption good with a technology that uses labor only. Each home firm $i$ has the production technology

$$
Y_{h, t}(i)=A_{t} N_{t}(i) \text {, all } s^{t}, 0 \leq t \leq T,
$$

where $Y_{h, t}(i)$ is the production of good $i, N_{t}(i)$ is the labor used in the production of good $i$, and $A_{t}$ is an aggregate technology shock in the home country. Good $i$ can be used for private and public consumption, $Y_{h, t}(i)=C_{h, t}(i)+C_{h, t}^{*}(i)+G_{t}(i)$. The technology in the foreign country is

$$
Y_{f, t}(j)=A_{t}^{*} N_{t}^{*}(j), \text { all } s^{t}, 0 \leq t \leq T,
$$

where the technology parameter $A_{t}^{*}$ is the same across firms but can be different from $A_{t}$. Each good $j$ produced in the foreign country can be consumed by households or 
by the foreign government, $Y_{f, t}(j)=C_{f, t}(j)+C_{f, t}^{*}(j)+G_{t}^{*}(j)$.

Prices are flexible. The firms in the home country choose prices to maximize profits $\Pi_{h, t}(i)=P_{h, t}(i) Y_{h, t}(i)-W_{t} N_{t}(i)$, given the demand functions

$$
Y_{h, t}(i)=\left(\frac{P_{h, t}(i)}{P_{h, t}}\right)^{-\theta} Y_{h, t}, \text { all } s^{t}, 0 \leq t \leq T
$$

where $Y_{h, t}=C_{h, t}+C_{h, t}^{*}+G_{t}$, obtained using the demand functions of the home good at home and abroad, and given the production functions (20).

The home firms set a common price $P_{h, t}(i)=P_{h, t}$ such that

$$
\frac{W_{t}}{P_{h, t}}=\frac{\theta-1}{\theta} A_{t}, \text { all } s^{t}, 0 \leq t \leq T,
$$

and the foreign firms set $P_{f, t}^{*}(j)=P_{f, t}^{*}$ where

$$
\frac{W_{t}^{*}}{P_{f, t}^{*}}=\frac{\theta-1}{\theta} A_{t}^{*}, \text { all } s^{t}, 0 \leq t \leq T .
$$

\subsection{Equilibrium}

We now define a flexible price equilibrium as a vector of allocations $\left\{C_{h, t}, C_{f, t}, N_{t}, C_{h, t}^{*}, C_{f, t}^{*}, N_{t}^{*}\right\}$ asset positions $\left\{M_{t}, B_{h, t}, B_{f, t}, B_{t+1}, M_{t}^{*}, B_{h, t}^{*}, B_{f, t}^{*}, B_{t+1}^{*}\right\}$, prices and policies

$$
\left\{P_{h, t}, W_{t}, R_{t}, Q_{t, t+1}, \tau_{h, t}, \tau_{f, t}, \tau_{n, t}, M_{t}^{S}, \varepsilon_{t}\right\} \text { and }\left\{P_{f, t}, W_{t}^{*}, R_{t}^{*}, Q_{t, t+1}^{*}, \tau_{h, t}^{*}, \tau_{f, t}^{*}, \tau_{n, t}^{*}, M_{t}^{* S}\right\}
$$

such that,

(a) Given the initial wealth levels, prices and policy the households choose the relevant quantities that solve their problems;

(b) Firms given prices and policy choose the relevant quantities that solve their problems;

(c) For initial public liabilities the governments satisfy their budget constraints; 
(d) The markets are in equilibrium:

$$
\begin{gathered}
C_{h, t}+C_{h, t}^{*}+G_{t}=A_{t} N_{t} \\
C_{f, t}+C_{f, t}^{*}+G_{t}^{*}=A_{t}^{*} N_{t}^{*} \\
M_{t}^{S}=M_{t} \\
M_{t}^{* S}=M_{t}^{*} \\
B_{t+1}=0 \\
B_{t+1}^{*}=0
\end{gathered}
$$

The market clearing in the labor and noncontingent bond markets was already imposed.

The equilibrium conditions that determine the allocations $\left\{C_{h, t}, C_{f, t}, N_{t}, C_{h, t}^{*}, C_{f, t}^{*}, N_{t}^{*}\right\}$, asset positions $\left\{M_{t}, B_{h, t}, B_{f, t}, B_{t+1}, M_{t}^{*}, B_{h, t}^{*}, B_{f, t}^{*}, B_{t+1}^{*}\right\}$, prices and policies

$$
\left\{P_{h, t}, W_{t}, R_{t}, Q_{t, t+1}, \tau_{h, t}, \tau_{f, t}, \tau_{n, t}, M_{t}^{S}, \varepsilon_{t}\right\} \text { and }\left\{P_{f, t}, W_{t}^{*}, R_{t}^{*}, Q_{t, t+1}^{*}, \tau_{h, t}^{*}, \tau_{f, t}^{*}, \tau_{n, t}^{*}, M_{t}^{* S}\right\}
$$
are (6) - (19), (22) - (29) and the intertemporal budget constraints of the home country that can be obtained by adding up the home government budget constraints and the home household budget constraints, as follows

$$
\sum_{s=t}^{T} E_{t} Q_{t, s+1}\left[P_{h, s}\left(C_{h, s}+G_{s}\right)+\varepsilon_{s} P_{f, s}^{*} C_{f, s}-W_{s} N_{s}-\Pi_{h, s}\right]=\mathbb{W}_{t}^{e}, \text { all } s^{t}, 0 \leq t \leq T,
$$

where $\mathbb{W}_{t}^{e}=\mathbb{W}_{t}-\mathbb{W}_{t}^{g}$, are the foreign assets owned by the home country. Using the market clearing conditions and the expression for profits, the constraints can be 
written as

$$
\sum_{s=t}^{T} E_{t} Q_{t, s+1}\left[\varepsilon_{s} P_{f, s}^{*} C_{f, s}-P_{h, s} C_{h, s}^{*}\right]=\mathbb{W}_{t}^{e}, \text { all } s^{t}, 0 \leq t \leq T
$$

\section{Equilibria under flexible prices}

Our purpose in this section is to assert a major result of the paper that has implications for equilibrium allocations with sticky prices and fixed exchange rates. We show that the set of equilibrium allocations under flexible prices can be implemented with policies such that the price level in either country will be constant over time, and such that the nominal exchange rate will also be constant over time. In order to do this we show that for a given equilibrium allocation $\left\{C_{h, t}, C_{f, t}, N_{t}, C_{h, t}^{*}, C_{f, t}^{*}, N_{t}^{*}\right\}$ the equilibrium conditions are all satisfied with constant producer price levels in each country equal to arbitrary numbers, and a constant nominal exchange rate, also equal to an arbitrary number.

The proposition follows:

Proposition 1 Any flexible equilibrium allocation can be implemented with $P_{h, t}=$ $P_{h, 0}, P_{f, t}^{*}=P_{f, 0}^{*}, \varepsilon_{t}=\varepsilon_{0}\left(\right.$ and $\left.R_{t}=R_{t}^{*}\right)$.

Proof: Without loss of generality we take $T=1$. In the beginning of period $t=2$ the assets market opens to liquidate debts. This means that the wealth of the households in period $t=2$, in either country, is zero, $\mathbb{W}_{2}=0$ and $\mathbb{W}_{2}^{*}=0$.

We take as given an arbitrary equilibrium allocation $\left\{C_{h, t}, C_{f, t}, N_{t}, C_{h, t}^{*}, C_{f, t}^{*}, N_{t}^{*}\right\}$ for $t=0,1$, in the set defined above. We show that there are constant prices with $P_{h, t}=P_{h, 0}, P_{f, t}^{*}=P_{f, 0}^{*}$, and fixed exchange rates, $\varepsilon_{t}=\varepsilon_{0}$, which implies that $R_{t}=R_{t}^{*}$, that satisfy the equilibrium equations for that allocation which are (6) - (19), (22) (29) and (31). 
First, this allocation satisfies trivially the two feasibility constraints, (24) and (25), as it is an equilibrium allocation. For given $P_{h, 0}, P_{f, 0}^{*}, \varepsilon_{0}$ we use the remaining equilibrium conditions to determine the values for the policy variables and remaining prices.

The firms' conditions determine $W_{t}$ and $W_{t}^{*}$

$$
\begin{aligned}
& \frac{W_{t}}{P_{h, 0}}=\frac{\theta-1}{\theta} A_{t}, t=0,1, \\
& \frac{W_{t}^{*}}{P_{f, 0}^{*}}=\frac{\theta-1}{\theta} A_{t}^{*}, t=0,1 .
\end{aligned}
$$

The period 0 intertemporal budget constraints for the two representative households are

$$
\sum_{t=0}^{1} \beta^{t} E_{0}\left[\left(u_{C_{h}}(t) C_{h, t}+u_{C_{f}}(t) C_{f, t}-u_{L}(t) N_{t}\right)\right]=\mathbb{W}_{0} \frac{u_{C_{h}}(0)}{P_{h, 0}\left(1+\tau_{h, 0}\right)}
$$

and

$$
\sum_{t=0}^{1} \beta^{t} E_{0}\left[\left(u_{C_{h}^{*}}(t) C_{h, t}^{*}+u_{C_{f}^{*}}(t) C_{f, t}^{*}-u_{L^{*}}(t) N_{t}^{*}\right)\right]=\mathbb{W}_{0}^{*} \frac{u_{C_{h}^{*}}(0)}{\frac{P_{h, 0}}{\varepsilon_{0}}\left(1+\tau_{h, 0}^{*}\right)}
$$

which are satisfied by appropriately choosing $\tau_{h, 0}$ and $\tau_{h, 0}^{*}$.

Given a common process for the nominal interest rate

$$
R_{t}=R_{t}^{*}
$$

to be determined later, and $\tau_{h, 0}$ and $\tau_{h, 0}^{*}$, can use the following equations

$$
\frac{u_{C_{h}}(0)}{\left(1+\tau_{h, 0}\right)}=\beta R_{0} E_{0} \frac{u_{C_{h}}(1)}{\left(1+\tau_{h, 1}\right)}
$$




$$
\begin{gathered}
\frac{u_{C_{h}^{*}}(0)}{\left(1+\tau_{h, 0}^{*}\right)}=\beta R_{0} E_{0} \frac{u_{C_{h}^{*}}(1)}{\left(1+\tau_{h, 1}^{*}\right)} \\
u_{C_{h}}(1) C_{h, 1}+u_{C_{f}}(1) C_{f, 1}-u_{L}(1) N_{1}=\mathbb{W}_{1} \frac{u_{C_{h}}(1)}{P_{h, 0}\left(1+\tau_{h, 1}\right)}, s^{1} \in S^{1} \\
u_{C_{h}^{*}}(1) C_{h, 1}^{*}+u_{C_{f}^{*}}(1) C_{f, 1}^{*}-u_{L^{*}}(1) N_{1}^{*}=\mathbb{W}_{1}^{*} \frac{u_{C_{h}^{*}(1)}}{\frac{P_{h, 0}\left(1+\tau_{h, 1}^{*}\right)}{\varepsilon_{0}}}, s^{1} \in S^{1}
\end{gathered}
$$

to determine $\tau_{h, 1}, \tau_{h, 1}^{*}, \mathbb{W}_{1}$ and $\mathbb{W}_{1}^{*}$.

Can use the intratemporal conditions

$$
\begin{aligned}
& \frac{u_{L}(t)}{u_{C_{h}}(t)}=\frac{W_{t}\left(1-\tau_{n, t}\right)}{P_{h, 0} R_{t}\left(1+\tau_{h, t}\right)}, t=0,1 \\
& \frac{u_{C_{h}}(t)}{u_{C_{f}}(t)}=\frac{\left(1+\tau_{h, t}\right) P_{h, 0}}{\left(1+\tau_{f, t}\right) \varepsilon_{0} P_{f, 0}^{*}}, t=0,1 \\
& \frac{u_{L_{t}^{*}}(t)}{u_{C_{f}^{*}}(t)}=\frac{W_{t}^{*}\left(1-\tau_{n, t}^{*}\right)}{P_{f, 0}^{*} R_{t}\left(1+\tau_{f, t}^{*}\right)}, t=0,1 \\
& \frac{u_{C_{h}^{*}}(t)}{u_{C_{f}^{*}}(t)}=\frac{\left(1+\tau_{h, t}^{*}\right) P_{h, 0}}{\left(1+\tau_{f, t}^{*}\right) \varepsilon_{0} P_{f, 0}^{*}}, t=0,1
\end{aligned}
$$

to determine $\tau_{n, t}, \tau_{f, t}, \tau_{n, t}^{*}, \tau_{f, t}^{*}$, for $t=0,1$.

We can use the cash in advance constraints

$$
\begin{aligned}
& \left(1+\tau_{h, t}\right) P_{h, 0} C_{h, t}+\left(1+\tau_{f, t}\right) \varepsilon_{0} P_{f, 0}^{*} C_{f, t}=M_{t}, t=0,1 \\
& \left(1+\tau_{h, t}^{*}\right) \frac{P_{h, 0}}{\varepsilon_{0}} C_{h, t}^{*}+\left(1+\tau_{f, t}^{*}\right) P_{f, 0}^{*} C_{f, t}^{*}=M_{t}^{*}, t=0,1
\end{aligned}
$$

to determine $M_{t}$ and $M_{t}^{*}$, for $t=0,1$.

The home country intertemporal budget constraints can be used to determine the nominal interest rates $R_{t}$. The budget constraints for period $t=1$ are 


$$
\mathbb{W}_{1}^{e}=\frac{1}{R_{1}}\left[\varepsilon_{0} P_{f, 0}^{*} C_{f, 1}-P_{h, 0} C_{h, 1}\right], s^{1} \in S^{1}
$$

which give $\# S^{1}$ interest rates $R_{1}$ as a function of the value for $\mathbb{W}_{1}^{e}$. Given these values for $R_{1}$ the budget constraint for period $t=0$,

$$
\begin{aligned}
\mathbb{W}_{0}^{e}= & \frac{1}{R_{0}}\left[\varepsilon_{0} P_{f, 0}^{*} C_{f, 0}-P_{h, 0} C_{h, 0}\right]+ \\
& E_{0} \frac{Q_{0,1}}{R_{1}}\left[\varepsilon_{0} P_{f, 0}^{*} C_{f, 1}-P_{h, 0} C_{h, 1}\right] .
\end{aligned}
$$

determines uniquely $R_{0}$.

The flexible price allocation can be supported with constant producer prices for both goods and a constant exchange rate, for arbitrary initial levels $P_{h, 0}, P_{f, 0}^{*}$ and $\varepsilon_{0}$. The common interest rate is a function of the level of the net foreign assets of the home country in period $t=1$. This, for the case of $t=0,1$, gives one degree of freedom for $\mathbb{W}_{1}^{e}$.

The proof extends to any finite horizon economy, $t=0, \ldots, T$, with $T$ arbitrarily large. There are $\# S^{t-1}$ degrees of freedom for $\mathbb{W}_{t}^{e}$ for every $t=1, \ldots, T$.

We have shown that for any equilibrium allocation, $\left\{C_{h, t}, C_{f, t}, N_{t}, C_{h, t}^{*}, C_{f, t}^{*}, N_{t}^{*}\right\}$, the equilibrium conditions can be satisfied by asset positions, prices and policies such that producer prices and exchange rates are arbitrary constants, $P_{h, t}=P_{h, 0}$, $P_{f, t}^{*}=P_{f, 0}^{*}, \varepsilon_{t}=\varepsilon_{0}$. This means that the full set of equilibrium allocations can be implemented under fixed exchange rates with producer prices in both countries that are constant over time.

Taxes play a particular role when equilibria have constant producer prices and exchange rates. Since prices are constant and so is the exchange rate, consumption taxes in one good relative to the other will have to move if relative prices are to 
move, which will happen in general if there are different shocks in different countries. Consumption taxes play another role, when public debt is noncontingent, that of replicating state-contingent real debt. We have assumed, as is standard in this literature, that internationally traded assets are state-noncontingent. Nominal interest rates, that in a fixed exchange rate regime are common across countries, can play the role of replicating state-contingent international debt. Consumption taxes also affect the households margin between consumption and labor. Labor income taxes will have to adjust for those effects. Since prices are constant and technologies in the two countries are varying, the nominal wages will have to move in response to shocks and move differently in different countries. Money supply will also have to move to respond to shocks to satisfy the cash in advance constraints.

One first implication of the result in the proposition is that fixed exchange rates do not restrict the set of allocations under flexible prices. This is an interesting result in itself, in particular, as in our model, when asset markets are incomplete. However, the issue of whether there are costs of a fixed exchange rate regime is typically associated with the presence of some type of price rigidity, as argued by Friedman (1953). If there are restrictions on how producer prices are set, and exchange rates are fixed, it may be the case that there will be restrictions on the relative prices of the goods produced in the different countries.

It is particularly surprising that fixed exchange rates do not restrict the set of allocations also when producer prices are constant over time. Can both producer prices and exchange rates be constant over time? Yes, as long as taxes can change so that the terms of trade, real wages, and debt levels can move with the shocks.

In the following section we assume that firms are restricted in the setting of prices. 


\section{$4 \quad$ Sticky prices}

The model considered above has full flexibility of prices and exchange rates. However, the discussion of the costs of the exchange rate regime is particularly interesting insofar as there is some type of nominal rigidity. We now assume that prices are sticky in some or in all goods produced. We start by showing that there are fiscal and monetary policies in a fixed exchange rate regime that can achieve any flexible price equilibrium allocation even when there are nominal rigidities that can be different across countries. Proposition 1 will be instrumental to show this result.

Under sticky prices there are allocations other than the ones that can be implemented under flexible prices. However, as we show here, those allocations are dominated in terms of welfare, so that indeed we can conclude that the fixed exchange rate regime is of no cost whether prices are flexible or sticky.

We assume that firms set prices as in Calvo (1983) staggered price setting, which is a commonly used assumption in the sticky price literature. We assume that the firms set prices in the currency of their country. In each country, starting from an historical common price, at every date, each firm can optimally set its price with some probability less than one, that can differ across countries. Because there is a continuum of firms, the probability is also the share of firms that optimally revise the price in each period.

In general, staggered price setting leads to inefficient differences in prices across firms. Although in a given country firms are otherwise identical, have the same linear technology and face identical demand functions, they may charge different prices. Thus, the relative price of the goods they produce may be different from one. The only case in which this will not occur is when firms that in each period have the opportunity of choosing a new price decide to maintain the same price. The price 
setting restrictions in this case will not be binding and the producer price level in each country will be constant. The equilibrium conditions will be identical to the equilibrium conditions of the flexible price economy when producer prices are constant across periods.

Since, as stated in Proposition 1, under flexible prices it is possible to implement the full set of equilibrium allocations with constant prices and fixed exchange rates, it follows that under sticky prices it is also possible to implement that same set, also with fixed exchange rates.

It is clear that under sticky prices there are allocations that are not implementable under flexible prices. That is the case whenever otherwise identical firms set different prices. It turns out, as we show in the Appendix, that the set of flexible price allocations dominates in terms of welfare the set of allocations under sticky prices. Since agents are heterogeneous across countries, the meaning of welfare dominance is the usual one, of a potential Pareto movement where lump sum transfers between agents are implicitly assumed.

Independently of the exchange rate regime, for each allocation that can be implemented under sticky prices there is one under flexible prices that can potentially improve welfare in both countries. The reason for this is that in order for sticky prices to be relevant, because different firms face different price setting restrictions, firms that use the same technology and face the same demand conditions will charge different prices. This means that production will be inefficient and the inefficiency in production is not optimal in this second best environment. This result relates to the one in Diamond Mirrlees (1971) that shows that it is not optimal to tax intermediate goods when there are consumption taxes on the final goods.

The proposition follows. 
Proposition 2 In a world economy with noncontingent bond markets and Calvo (1983) staggered price setting there is no cost of a fixed exchange rate regime, independently of the degree of price rigidity.

Proof (sketch): In Proposition 1 we show that the set of allocations under flexible prices is implemented with policies that generate constant prices and exchange rates, equal to arbitrary numbers. For the policies that induce prices to be equal to the historical initial prices of the Calvo firms, $P_{h, 0}$ and $P_{f, 0}^{*}$, and exchange rates equal to any constant ${ }^{9}$, the equilibrium conditions under Calvo (1983) will be exactly the ones under flexible prices. This establishes that the flexible price set of allocations is feasible with Calvo price setting and fixed exchange rates. It remains to show that the set is optimal, in the sense that for every allocation in the set under sticky prices, there is one in the set under flexible prices that is a potential Pareto improvement. This is done in the Appendix.

The result in this proposition can be extended to any other form of price stickiness, such as prices set in advance as in Ireland (1996), Taylor (1980) staggered prices, Rotemberg (1982) adjustment costs of changing prices, or Dotsey, King and Wolman (1999). For the case where prices are set in advance, let the initial prices $P_{h, 0}$ and $P_{f, 0}^{*}$ be exogenously given and the other period prices $P_{h, t}$ and $P_{f, t}^{*}$ be set in advance for $k$ periods, for a finite $k$. Proposition 1 implies that adding those restrictions to the flexible price economy still allows to implement the set of allocations under flexible prices, in a fixed exchange rate regime. The argument of welfare dominance of the flexible price set also applies here.

We have analyzed flexible versus fixed exchange rate regimes. The analysis clearly follows through in a monetary union. The interest rate will be common as under fixed

\footnotetext{
${ }^{9}$ The exchange rate could be equal to one for the case of a monetary union,
} 
exchange rates. The money supply in each country obviously does not have to be the same.

We have assumed that prices are set in the currency of the producer. We could alternatively have assumed local currency pricing. The results would follow through. For the policies that support constant producer prices and constant exchange rates, local currency price setting restrictions would not have any impact. Contrary to what is argued extensively in the literature that does not allow for fiscal policy instruments, it does not make a difference whether prices are set in the currency of the producer or the consumer.

\section{$5 \quad$ Labor mobility}

In the literature of optimal currency areas the lack of labor mobility is one of the justifications for the costs of a monetary union with asymmetric member countries. A result of this paper is that the opposite is true. Labor immobility is a necessary condition for the irrelevance of the exchange regime.

Proposition 1 was stated for the case where labor cannot move across countries. It does not apply when labor is mobile. To see this we assume that workers can choose to work in foreign firms being taxed at home. They consume at home. This is one way of modelling labor mobility. There are alternative ways but the same arguments go through.

For the home households, total labor $N_{t}$ is split between work at home $N_{h, t}$ and work abroad $N_{f, t}$,

$$
N_{t}=N_{h, t}+N_{f, t} .
$$

Similarly for the foreign country, $N_{t}^{*}$ is split between $N_{h, t}^{*}$, which is labor in the home 
country, and $N_{f, t}^{*}$, which is labor in the foreign country,

$$
N_{t}^{*}=N_{h, t}^{*}+N_{f, t}^{*} .
$$

The market clearing conditions in the goods market, (24), become

$$
\begin{aligned}
& C_{h, t}+C_{h, t}^{*}+G_{t}=A_{t}\left[N_{h, t}+N_{h, t}^{*}\right] \\
& C_{f, t}+C_{f, t}^{*}+G_{t}^{*}=A_{t}^{*}\left[N_{f, t}+N_{f, t}^{*}\right]
\end{aligned}
$$

The conditions of the households problem are the same except for an additional arbitrage condition on where to work, that equates the two wages

$$
W_{t}=\varepsilon_{t} W_{t}^{*}
$$

The price setting conditions for the firms are also unchanged. The country budget constraints (31) become

$$
\begin{aligned}
& \sum_{s=t}^{T} E_{t} Q_{t, s+1}\left[\varepsilon_{s} P_{f, s}^{*} C_{f, s}-P_{h, s} C_{h, s}^{*}+W_{s} N_{h, s}^{*}-\varepsilon_{s} W_{s}^{*} N_{f, s}\right] \\
= & \mathbb{W}_{t}-\mathbb{W}_{t}^{g}, \text { all } s^{t}, 0 \leq t \leq T,
\end{aligned}
$$

Notice that full labor mobility implies one additional constraint per state to the equilibrium conditions. The wage in the same currency must be equal across countries. As shown in the proof of Proposition 1, there are multiple policies that support each allocation under flexible prices with constant prices and exchange rates. Under sticky prices and fixed exchange rates the degrees of freedom are the number of states at $t-1, \# S^{t-1}$, for each period $t$. These degrees of freedom are not enough to satisfy 
the additional equilibrium restrictions, which are as many as the number of states in $t, \# S^{t}$. This is stated in the proposition below.

Proposition 3 When prices are sticky, in a fixed exchange rate regime (or monetary union), labor immobility is a necessary condition to implement the set of flexible price equilibrium allocations.

Proof: The nominal wages cannot satisfy simultaneously the price setting conditions (22) and (23), with $P_{h, t}=P_{h, 0}$ and $P_{f, t}^{*}=P_{f, 0}^{*}$,

$$
\frac{W_{t}}{P_{h, 0}}=\frac{\theta-1}{\theta} A_{t}, \text { all } s^{t}, 0 \leq t \leq T
$$

and

$$
\frac{W_{t}^{*}}{P_{f, 0}^{*}}=\frac{\theta-1}{\theta} A_{t}^{*}, \text { all } s^{t}, 0 \leq t \leq T,
$$

and the arbitrage condition

$$
W_{t}=\varepsilon_{0} W_{t}^{*}
$$

Therefore the equilibrium allocations under flexible prices and exchange rates with mobile labor cannot be decentralized with constant exchange rates and producer prices.

When labor is mobile, and prices are sticky, the exchange rate regime matters. In particular, while with flexible exchange rates it is possible to implement the set of allocations under flexible prices, that is not the case in a fixed exchange rate regime.

The fact that with labor mobility there are costs of a fixed exchange rate regime, while there are no such costs when labor is immobile, does not mean that labor mobility is undesirable. We are not comparing environments with and without labor mobility, but rather environments with and without fixed exchange rates, when labor is immobile or when it is mobile. 


\section{Concluding remarks}

In this paper we address the central issues in the literature on optimal currency areas using the approach of optimal fiscal and monetary policy in general equilibrium. We could summarize the results with the claim that every currency area is an optimal currency area, provided labor is not mobile. This extreme result is in contrast with the bulk of the literature on optimal currency areas, starting with Mundell (1961).

Under a flexible exchange rate regime, monetary policy in each country can freely respond to shocks; may respond to country specific shocks or may respond differently from other countries to common shocks. Instead, in a monetary union there is a unique monetary policy for the members of the union. This implies restrictions in the use of policy; the exchange rate must be constant over time and the nominal interest rate must be equal across countries. Are these restrictions relevant to achieve the optimal equilibrium allocations? Does the answer to this question change with the introduction of nominal rigidities, like staggered price setting? Does it matter that international capital markets are segmented, and whether labor is mobile?

The conventional wisdom is that there are costs of a fixed exchange rate regime, or a monetary union, resulting from the loss in ability to use policy for stabilization purposes. The costs are taken to be higher the stronger are the asymmetries across countries in shocks and their transmission, and the stronger are the nominal rigidities. Instead, we show that in an environment with nominal rigidities, whatever the type of price setting PCP (producer currency pricing) or LCP (local currency pricing), the exchange rate regime, whether flexible or fixed exchange rates, is irrelevant once fiscal policy instruments are taken into account. We also show that in order for the costs of the monetary union to be zero labor cannot be mobile.

One final comment: Friedman (1953) made the point that, in a world with sticky 
prices, exchange rates should be flexible in order for relative prices to be adjusted. We make a further point that in a world where prices are sticky and exchange rates cannot move there are still policy instruments that can replace the role of the price level and the exchange rate. Note that the adjustments in fiscal policy are not automatic and would require a knowledge of the model and the shocks to be fully effective. But neither would the movements in exchange rates that would be necessary to accomplish the same goal. The information that is necessary to conduct policy under flexible exchange rates so that the path for exchange rates is a particular one is exactly the same information necessary to affect directly the relative prices using tax rates.

\section{Appendix: Allocations under flexible and sticky prices}

In this appendix we show that for each allocation under sticky prices, with flexible exchange rates, there is an allocation under flexible prices that gives at least as high welfare to one country without reducing the welfare of the other country.

Assuming that lump sum transfers are feasible between countries, the set of im-

plementable allocations under flexible prices $\left\{C_{h, t}, C_{f, t}, N_{t}, C_{h, t}^{*}, C_{f, t}^{*}, N_{t}^{*}\right\}$ as well as initial taxes and exchange rate $\left\{\tau_{h, 0}, \tau_{h, 0}^{*}, \varepsilon_{0}\right\}$ will be characterized by the following conditions:

$$
\begin{gathered}
\sum_{t=0}^{1} \beta^{t} E_{0}\left[\left(u_{C_{h}}(t) C_{h, t}+u_{C_{f}}(t) C_{f, t}-u_{L}(t) N_{t}\right)\right]=\mathbb{W}_{0} \frac{u_{C_{h}}(0)}{P_{h, 0}\left(1+\tau_{h, 0}\right)} \\
\sum_{t=0}^{1} \beta^{t} E_{0}\left[\left(u_{C_{h}^{*}}(t) C_{h, t}^{*}+u_{C_{f}^{*}}(t) C_{f, t}^{*}-u_{L^{*}}(t) N_{t}^{*}\right)\right]=\mathbb{W}_{0}^{*} \frac{u_{C_{h}^{*}}(0)}{\frac{P_{h, 0}}{\varepsilon_{0}}\left(1+\tau_{h, 0}^{*}\right)} \\
C_{h, t}+C_{h, t}^{*}+G_{t}=A_{t} N_{t},
\end{gathered}
$$




$$
C_{f, t}+C_{f, t}^{*}+G_{t}^{*}=A_{t}^{*} N_{t}^{*}
$$

We do not impose as a restriction the budget constraint between countries, because we allow for transfers between these. The remaining equilibrium conditions determine the policy and prices. Denote the set of allocations that satisfy these conditions by $E^{f}$.

Given Pareto weights there will be an optimal allocation that can be decentralized with a choice of initial conditions $\mathbb{W}_{0}^{e}$. The Pareto weights can be chosen to be such that the optimal allocation is implemented with the actual initial $\mathbb{W}_{0}^{e}$.

Under sticky prices the set of equilibrium conditions cannot be summarized by a small set of implementability conditions as under flexible prices. The allocations $\left\{C_{h, t}, C_{f, t}, N_{t}, C_{h, t}^{*}, C_{f, t}^{*}, N_{t}^{*}\right\}$ are restricted by the same intertemporal budget constraints as in the flexible price case above, (40) and (41). For given prices $\left\{\frac{P_{h, t}(i)}{P_{h, t}}, \frac{P_{f, t}(j)}{P_{f, t}}\right\}$, they are restricted by the feasibility conditions

$$
\begin{gathered}
\left(C_{h, t}+C_{h, t}^{*}+G_{t}\right) \int_{0}^{1}\left(\frac{P_{h, t}(i)}{P_{h, t}}\right)^{-\theta} d i=A_{t} N_{t} \\
\left(C_{f, t}+C_{f, t}^{*}+G_{t}^{*}\right) \int_{0}^{1}\left(\frac{P_{f, t}(j)}{P_{f, t}}\right)^{-\theta} d j=A_{t}^{*} N_{t}^{*}
\end{gathered}
$$

the conditions that define the aggregate price levels, $P_{h, t}=\left[\int_{0}^{1} P_{h, t}(i)^{1-\theta} d i\right]^{\frac{1}{1-\theta}}$ and $P_{f, t}^{*}=\left[\int_{0}^{1} P_{f, t}^{*}(j)^{1-\theta} d j\right]^{\frac{1}{1-\theta}}$, as well as all the remaining equilibrium conditions. Let the set of allocations that satisfy these restrictions be denoted by $E^{s}$.

It is straightforward to show that $D \equiv \int_{0}^{1}\left(\frac{P_{h, t}(i)}{P_{h, t}}\right)^{-\theta} d i \geq 1$ and $D^{*}=\int_{0}^{1}\left(\frac{P_{f, t}(j)}{P_{f, t}}\right)^{-\theta} d j$ $\geq 1$. $D=1$ when $\frac{P_{h, t}(i)}{P_{h, t}}=1$ and $D^{*}=1$ when $\frac{P_{f, t}(j)}{P_{f, t}}=1$.

The set of allocations under flexible prices dominates the set under sticky prices, meaning that for each allocation in $E^{s}$ there is at least one allocation in $E^{f}$ with at 
least one of the goods in larger or equal quantity and none smaller. The intertemporal budget constraints are the same but the feasibility conditions are different, being 44 and 45 more restrictive than 42 and 43 , and there are additional equilibrium

restrictions over $E^{s}$ that are absent from $E^{f}$. Moreover, the restrictions over the allocations under sticky prices are exactly the same only when $P_{h, t}(i)=P_{h, 0}$ and $P_{f, t}(j)=P_{f, 0}$

\section{References}

[1] Aiyagari, R, A. Marcet, T. Sargent and J. Seppala. 2002. "Optimal Taxation without State-contingent Debt." J. P. E. 110: 1220-1254.

[2] Angeletos, George-Marios. 2002. "Fiscal Policy with Non-contingent Debt and the Optimal Maturity Structure," Q. J. E. 117: 1105-1131.

[3] Benigno, G. and B. Paoli. 2004. "Fiscal and Monetary Policy in a Small Open Economy". Mimeo, L.S.E.

[4] Benigno, P.. 2004. "Optimal Monetary Policy in a Currency Area". J. Intern. Econ 63, 2: 293-320.

[5] Benigno, Pierpaolo and Michael Woodford. 2003. "Optimal Monetary and Fiscal Policy: A Linear Quadratic Approach." In NBER Macroeconomics Annual, edited by . Cambridge, Mass. : MIT Press.

[6] Benigno, Pierpaolo and Michael Woodford. 2003. "Optimal Monetary and Fiscal Policy: A Linear Quadratic Approach." In NBER Macroeconomics Annual, edited by . Cambridge, Mass. : MIT Press. 
[7] Buera, Francisco and Juan Pablo Nicolini. 2004. "Optimal Maturity of Government Debt without State Contingent Bonds." J. Monetary Econ. 51, 3: 531-554.

[8] Calvo, G.. 1983. "Staggered Prices in a Utility-Maximizing Framework." J. Monetary Econ. 12: 383-398.

[9] Chari, V. V., Lawrence Christiano and Patrick Kehoe. 1991. "Optimal Fiscal and Monetary Policy: Some Recent Results." J. Money, Credit, and Banking 23: 519-539.

[10] Chari, V. V., and Patrick Kehoe, 1999. "Optimal Fiscal and Monetary Policy." In Handbook of Macroeconomics, vol 1C, edited by John Taylor and Michael Woodford. North-Holland.

[11] Cooper, R. and H. Kempf. 2004. "Overturning Mundell: Fiscal Policy in a Monetary Union" . Rev. Econ. Stud. 71, 2. 371-397.

[12] Correia, I., J. P. Nicolini and P. Teles. 2002. "Optimal Fiscal and Monetary Policy: Equivalence Results." Fed. Reserve Bank Chicago WP-02-16 (November).

[13] Corsetti, G.. 2005. "Monetary Policy in Heterogeneous Currency Unions: Reflections Based on a Micro-Founded Model of Optimum Currency Areas." Mimeo. Europ. Univ. Inst.

[14] Corsetti, G.. 2006. "A Micro-founded Reconsideration of the

[15] Theory of Optimum Currency Areas." Mimeo. Europ. Univ. Inst.

[16] Corsetti, G. and P. Pesenti. 2002. "Endogenous pass-through and Optimal Monetary Policy: A Model of Self Validating Exchange Rate Regimes." Mimeo. Europ. Univ. Inst. 
[17] Devereux, M. and C. Engle. 2003. "Monetary Policy in the Open Economy Revisited: Exchange Rate Flexibility and Price Setting Behaviour". Rev. Econ. Stud. 70: 765-783.

[18] Diamond, P. A. and J. A. Mirrlees. 1971. "Optimal Taxation and Public Production." A. E. R. 61, (1, 3): 8-27, 261-268.

[19] Dotsey, Michael, Robert G. King and Alexander Wolman. 1999. "State Dependent Pricing and the General Equilibrium Dynamics of Money and Output." $Q$. J. E. 114 (May): 655-690.

[20] Duarte, M.. 2004. "Monetary Policy and the Adjustment to Country Specific Shocks." Mimeo. Fed. Res. Bank of Richmond.

[21] Duarte, M. and M. Obstfeld. 2005. "Monetary Policy in the Open Economy Revisited: The Case for Exchange Rate Flexibility". Rev. Econ. Stud., forthcoming.

[22] Ferrero, A.. 2005. "Fiscal and Monetary Rules for a Currency Union." Mimeo. NYU.

[23] Friedman, M., 1953. "The Case for Flexible Exchange Rates" in Essays in Positive Economics, Chicago, Il. Univ. of Chicago Press: 157-203.

[24] Gali, J. and T. Monacelli. 2005. "Optimal Monetary and Fiscal Policy in a Currency Union." Mimeo. UPF.

[25] Ireland, Peter. 1996. "The Role of Countercyclical Monetary Policy." J.P.E. 104 (4): 704-23.

[26] Lucas, Robert E., Jr. and Nancy L. Stokey. 1983. "Optimal Fiscal and Monetary Policy in an Economy without Capital." J. Monetary Econ. 12: 55-93. 
[27] Mundell, Robert. 1961. "A Theory of Optimum Currency Areas." Amer. Econ. Rev. 51: 657-675.

[28] Nicolini, Juan Pablo and Constantino Hevia. 2004. "Optimal Devaluations." Mimeo. Univ. Di Tella.

[29] Obstfeld, 2004, "Pricing to market, the Interest Rate and the Exchange Rate." Mimeo. Univ. Calif. Berkeley.

[30] Rotemberg, Julio J. 1982. "Sticky Prices in the United States." J. Economic Policy 90: 1187-1211.

[31] Schmitt-Grohé, Stephanie and Martin Uribe. 2004. "Optimal Fiscal and Monetary Policy under Sticky Prices.” J. Econ. Theory 114: 198-230.

[32] Siu, Henry. 2004. "Optimal Fiscal and Monetary Policy with Sticky Prices." J. Monetary Econ. 51: 250-289.

[33] Taylor, John. 1980. "Aggregate Dynamics and Staggered Contracts." J. P. E. 88: 1-23. 